\title{
Effects of Platelet-derived Growth Factor and Other Polypeptide Mitogens on DNA Synthesis and Growth of Cultured Rat Liver Fat-storing Cells
}

Massimo Pinzani, Loreto Gesualdo, “ Ghaleb M. Sabbah, and Hanna E. Abboud

Departments of Medicine and *Pathology, Case Western Reserve University, Cleveland, Ohio 44106

\begin{abstract}
In vitro and in vivo studies suggest that liver fat-storing cells (FSC) may play an important role in the development of liver fibrosis. We explored the effects of platelet-derived growth factor (PDGF), epidermal growth factor (EGF), transforming growth factor (TGF)-alpha and TGF-beta, and basic fibroblast growth factor (bFGF) on DNA synthesis and growth of rat liver FSC. PDGF, EGF, TGF-alpha, and bFGF induced a dose-dependent increase in DNA synthesis with a peak effect at $24 \mathrm{~h}$. PDGF produced the most striking effect with a maximum 18-fold increase over control. EGF, TGF-alpha, and bFGF elicited a maximum three- to fourfold increase in DNA synthesis. Analysis of growth curves revealed a similar pattern of potency of the growth factors. TGF-beta did not affect DNA synthesis of FSC; however, TGF-beta markedly potentiated the stimulatory effects of both EGF and PDGF. FSC showed high specific binding of ${ }^{125}$ I-PDGF and Scatchard analysis revealed high affinity receptors with an apparent $K_{d}$ of $\mathbf{2 . 3}$ $\times 10^{-10} \mathrm{M}$. Our data suggest that PDGF is a key mitogen for FSC and that the coordinate release of other growth factors together with PDGF by inflammatory cells represents a potent potential stimulus for FSC proliferation in conditions of chronic self-perpetuating liver inflammation.
\end{abstract}

\section{Introduction}

Liver fat-storing cells (FSC) ${ }^{1}$ referred to as Ito cells or lipocytes are nonparenchymal cells of mesenchymal origin situated in the space of Disse, between the sinusoidal endothelium and hepatocytes. Recent studies have demonstrated an important role for these cells in hepatic vitamin A metabolism (1) and in the production of several matrix components. FSC isolated from rat liver and maintained in culture have been shown to secrete collagen (mainly types I and III; 2-4), laminin (5), proteoglycans (6), and fibronectin $(2,7)$. Actually, FSC represent the main source of collagen in primary hepatocyte cultures (8) and in vivo studies have also supported a role in fibrogenesis. Active proliferation of FSC in intralobular fi-

Address correspondence and reprint requests to Dr. Hanna E. Abboud, V.A. Medical Center, Medical Research, 151(W), 10701 East Blvd., Cleveland, $\mathrm{OH} 44106$.

Received for publication 15 May 1989 and in revised form 5 September 1989.

1. Abbreviations used in this paper: bFGF, basic fibroblast growth factor; EGF, epidermal growth factor; FSC, fat-storing cells; PDGF, platelet-derived growth factor; $\left[{ }^{3} \mathrm{H}\right] \mathrm{TdR},\left[\right.$ methyl- $\left.{ }^{3} \mathrm{H}\right]$ thymidine; TGF, transforming growth factor.

The Journal of Clinical Investigation, Inc.

Volume 84, December 1989, 1786-1793 brous septa associated with changes in cell morphology (progression from typical FSC to transitional cells to myofibroblasts) and increased collagen synthesis have been observed in animal models of liver fibrosis (9-13) and in human subjects with alcoholic liver disease (14).

Chronic tissue inflammation is characterized by the presence of cell types that have the potential to synthesize and secrete cytokines and peptide growth factors. For example, platelet-derived growth factor (PDGF) is released in high concentrations during tissue repair and inflammatory processes, first from platelet alpha granules and subsequently by activated macrophages (15-17). Other peptide growth factors that have been shown to be actively released from platelets and activated macrophages, together with PDGF, include epidermal growth factor (EGF), transforming growth factor (TGF)alpha, TGF-beta, and basic fibroblast growth factor (bFGF; 18). Parenchymal and nonparenchymal liver cells have also been shown to express mRNAs for peptide growth factors (e.g., TGF-alpha and TGF-beta) that seem to regulate hepatocyte growth after partial hepatectomy $(19,20)$.

There is very little information about the factors that regulate FSC growth. Preliminary observations suggest that FSC growth may be stimulated by Kupffer cells partly via release of PDGF-like activity (21). In addition, tumor necrosis factoralpha and IL-1-alpha appear to stimulate, whereas TGF-beta may inhibit, DNA synthesis in FSC (22). In the present study we explored the effects of PDGF and various polypeptide growth factors on DNA synthesis and growth of well-characterized rat FSC. Our findings suggest that these peptide growth factors play a key role in regulating growth of FSC.

\section{Methods}

\section{Materials}

Peptide growth factors. Recombinant PDGF $\left(\mathrm{PDGF}_{\mathrm{v}-\mathrm{sis}}\right)$ and bFGF were purchased from Amgen Biologicals (Thousand Oaks, CA); purified human TGF-alpha was from Bachem (Torrance, CA); purified human TGF-beta was from R\&D Systems, Inc. (Minneapolis, MN); purified receptor grade EGF was obtained from Collaborative Research Inc. (Lexington, MA). For the PDGF receptor binding study radioiodinated human platelet PDGF was purchased from Cambridge Medical Technology Corporation (Billerica, MA) and nonlabeled PDGF purified from human platelets ( $96 \%$ pure) was obtained from R\&D Systems.

\section{Cell isolation and culture}

Liver FSC were isolated from the liver of male Sprague-Dawley rats weighing 450-550 g (Charles River Breeding Laboratories, Inc., Wilmington, MA) according to Friedman and Roll (23) with minor modifications. The cell suspension obtained after digesting the liver with pronase (103 proteolytic units/mg; Calbiochem-Behring Corp., San Diego, CA) and collagenase type IV-S (Sigma Chemical Co., St. Louis, MO) was filtered through a $105-\mu \mathrm{m}$ nylon gauze and washed three times at $500 \mathrm{~g}$ for $10 \mathrm{~min}$ in $90 \mathrm{ml}$ of HBSS without calcium and magnesium (Gibco Laboratories, Grand Island, NY) containing 10 
$\mu \mathrm{g} / \mathrm{ml}$ of DNase (bovine pancreas; Calbiochem-Behring Corp.). The cell pellet was finally resuspended in $25 \mathrm{ml}$ of HBSS containing 10 $\mu \mathrm{g} / \mathrm{ml}$ of DNase and antibiotics, and evenly distributed over four gradients of stractan (Larex-LO; Larex International Co., Tacoma, WA) with densities of $1.053,1.058,1.090$, and 1.111 in Ultra-clear 13-ml ultracentrifuge tubes (Beckman Instruments, Inc., Palo Alto, CA). Tubes were then centrifuged at $20,000 \mathrm{rpm}$ for $30 \mathrm{~min}$ at $25^{\circ} \mathrm{C}$ in a rotor (model SW40; Beckman Instruments, Inc.). After centrifugation FSC were recovered from the interface between the 1.053 stractan gradient layer and the medium. The total number of cells recovered at this level was, on average, $4 \times 10^{6}$ cells/g of liver and were $>95 \%$ viable as assessed by Trypan blue exclusion. The recovered cell suspension was then washed twice in $25 \mathrm{ml}$ of DME (Gibco Laboratories) with antibiotics at $500 \mathrm{~g}$ for $10 \mathrm{~min}$ and finally resuspended in Waymouth's MB 752/1 medium (Gibco Laboratories) supplemented with $15 \mathrm{mM}$ Hepes, $0.6 \mathrm{U} / \mathrm{ml}$ insulin, $2 \mathrm{mM}$ glutamine, $0.1 \mathrm{mM}$ nonessential amino acids, $1 \mathrm{mM}$ sodium pyruvate, antibiotic-antifungal solution, $10 \%$ horse serum (gammaglobulin free; Gibco Laboratories), and 10\% calf serum (HyClone Laboratories, Inc., Logan, UT). The cells were plated in plastic tissue culture dishes or flasks (Costar, Cambridge, MA) at a density of $0.2-0.5 \times 10^{6}$ cells $/ \mathrm{ml}$ and incubated at $37^{\circ} \mathrm{C}$ in $5 \%$ $\mathrm{CO}_{2}$. The medium was replaced $24 \mathrm{~h}$ after plating and every $48-72 \mathrm{~h}$ thereafter. Primary cultures of the cells were allowed to grow for 10-15 $\mathrm{d}$, at which time period the cultured cells were confluent. For further passage, confluent cells were washed with HBSS and removed with $0.025 \%$ trypsin/0.5 mM EDTA in calcium- and magnesium-free Dulbecco's PBS (Gibco Laboratories) and plated in Waymouth's medium.

\section{Morphologic characterization of rat FSC}

Immunofluorescence and immunoperoxidase studies. Primary and passage 2 cells at 4-6 d after plating on sterile tissue culture chamber slides (Lab-Tek, Naperville, IL) were used for indirect immunoperoxidase and immunofluorescence studies. The cells were identified by staining for intermediate filaments and surface antigens. For these studies cells were washed in Dulbecco's PBS, fixed in 5\% acetic acid in absolute ethanol or in acetone, and stained with antibodies using the avidin-biotin immunoperoxidase method (Vector Laboratories, Burlingame, CA) for mouse antibodies, or the peroxidase-antiperoxidase method (Organon Teknika-Cappel Laboratories, Malvern, PA) for rabbit antibodies, and fluoresceinated goat anti-rabbit or anti-mouse IgG (United States Biochemical Corp., Cleveland, $\mathrm{OH}$ ). The primary antibodies used were murine MAbs to desmin (Biogenex Laboratories, Dublin, CA), cytokeratin (MAK 6; Triton Biosciences, Alameda, CA), rat Ia (common part determinant; Sera-lab, Westbury, NY), and rabbit polyclonal antibodies to human fibronectin and laminin (both from Bethesda Research Laboratories, Bethesda, MD), Factor VIII (Boehringer Mannheim Biochemical, Indianapolis, IN), myoglobin (Organon Teknika-Cappel Laboratories), and vimentin (Polysciences, Inc., Warrington, PA). Antibodies to myoglobin crossreact with myosin filaments. Nonimmune IgG from the appropriate species was used as a negative control in each case. To further exclude Kupffer cell contamination the cells were stained for endogenous peroxidase upon incubation with diaminobenzidine $/ \mathrm{H}_{2} \mathrm{O}_{2}$ as described by Wisse (24). Actin filaments were stained using the rhodamine-phalloidin complex (Molecule Probes Inc., Junction City, OR) after fixation in formaldehyde. The characteristic fading green-blue fluorescence due to the presence of vitamin A was analyzed under fluorescence microscopy by exposing the cells to ultraviolet light at $330 \mathrm{~nm}$. Cell morphology was studied using an inverted microscope IMR2 (Olympus Corporation of America, New Hyde Park, NY) with Hoffman optics, a light microscope BH-2 (Olympus Corporation of America), an immunofluorescence (E. Leitz, Inc., Rockleigh, NJ) microscope and a 100CX transmission electron microscope (JEOL USA, Peabody, MA).

\section{Effects of polypeptide growth factors on $\left[{ }^{3} \mathrm{H}\right]$ thymidine incorporation}

DNA synthesis was measured as the amount of [methyl- $\left.{ }^{3} \mathrm{H}\right]$ thymidine $\left(\left[{ }^{3} \mathrm{H}\right] \mathrm{TdR}\right)$ incorporated into TCA-precipitable material. Cells were plated in 24-well dishes at a density of $2 \times 10^{4}$ cells/well and incubated with Waymouth's medium containing $10 \%$ horse serum and $10 \%$ calf serum until they became confluent (density of $\sim 1.0 \times 10^{5}$ cells/well). Confluent cells were made quiescent by placing them in Waymouth's medium supplemented with $1 \%$ Zeta serum, a low mitogenicity serum (AMF, Meriden, CT), for $48 \mathrm{~h}$. Unless otherwise specified, cells were incubated with or without various growth factors for $20 \mathrm{~h}$ and then pulsed for $4 \mathrm{~h}$ with $1.0 \mu \mathrm{Ci} / \mathrm{ml}$ of $\left[{ }^{3} \mathrm{H}\right] \mathrm{TdR}(6.7 \mathrm{Ci} / \mathrm{mmol}$; New England Nuclear, Boston, MA) for $4 \mathrm{~h}$. At the end of the pulsing period medium was carefully aspirated, ice-cold 5\% TCA was added, and dishes were kept on ice for $15 \mathrm{~min}$. After two additional washes with $5 \%$ TCA cells were solubilized by adding $750 \mu \mathrm{l}$ of $0.25 \mathrm{~N} \mathrm{NaOH}, 0.1 \%$ SDS. $0.5 \mathrm{ml}$ of the solubilized cell solution was then neutralized with $50 \mu \mathrm{l}$ of $6 \mathrm{~N} \mathrm{HCl}$ and counted in a scintillation counter. Cell number was determined in three separate wells from each dish after trypsinization and counting in a Coulter counter (Coulter Electronics Inc., Hialeah, FL).

\section{Autoradiography}

Rat FSC were plated on slides (Lab-Tek) in Waymouth's medium supplemented with serum. Once the cells reached confluency they were made quiescent as described above and then incubated with various growth factors for $20 \mathrm{~h}$ followed by a 4-h pulse with $\left[{ }^{3} \mathrm{H}\right] \mathrm{TdR}(1$ $\mu \mathrm{Ci} / \mathrm{ml})$. At the end of the pulsing period an equal volume of freshly prepared 3:1 methanol/acetic acid was added to the medium for 10 min. The above half-strength fixative was then replaced by an equal volume of undiluted 3:1 methanol/acetic acid fixative. After $10 \mathrm{~min}$ cells were air-dried and exposed to NTB-2 nuclear emulsion (Eastman Kodak Co., Rochester, NY) for $3 \mathrm{~d}$ at $4^{\circ} \mathrm{C}$. The slides were then developed and fixed with D19 developer and fixer (Eastman Kodak Co.), respectively, and stained with Giemsa (25). 200 cells per each incubation were counted and percent of labeled nuclei (labeling index) was determined.

\section{Cell growth in response to peptide growth factors}

Rat FSC were plated in 12-well dishes at a density of $4 \times 10^{4}$ cells/well or in 24-well dishes at a density of $2 \times 10^{4}$ cells/well in Waymouth's medium with serum. After $24 \mathrm{~h}$ the cells were washed and placed in Waymouth's medium containing $1 \%$ Zeta serum for $48 \mathrm{~h}$. This medium was removed and cells were placed in fresh Waymouth's medium with $1 \%$ Zeta serum containing the conditions to be tested (time 0 ). Cell counts were performed on triplicate wells at time 0 and after 3 and $6 \mathrm{~d}$ by trypsinizing the cells and using a Coulter counter (Coulter Electronics Inc.). Fresh medium and test conditions were added to the remaining wells at each time point. Results were expressed as percent increment in the presence of the growth factors as compared with cells incubated in medium alone.

\section{Binding of PDGF to rat FSC}

Confluent FSC in 24-well dishes at a density of $1.0 \times 10^{5}$ cells/well were made quiescent by placing them in Waymouth's medium supplemented with $1 \%$ Zeta serum for $48 \mathrm{~h}$. Cells were then washed twice with binding buffer that consisted of $50 \%$ Dulbecco-Vogt modified Eagle's Medium (Gibco Laboratories), 50\% Ham's F12 nutrient mixture (Gibco Laboratories), $25 \mathrm{mM}$ Hepes, $2 \mathrm{mg} / \mathrm{ml} \mathrm{BSA} \mathrm{(gammaglob-}$ ulin free; Sigma Chemical Co.), pH 7.4, and triplicate wells were incubated with increasing concentrations of ${ }^{125}$ I-PDGF $(21,000 \mathrm{cpm} / \mathrm{ng})$ for $2 \mathrm{~h}$ at $4^{\circ} \mathrm{C}$ with constant gentle rotary agitation. At the end of the incubation period the cells were washed three times with ice-cold Dulbecco's PBS containing $1 \mathrm{mM} \mathrm{CaCl}_{2}$ and $2 \mathrm{mg} / \mathrm{ml} \mathrm{BSA}$. The monolayer was then solubilized by adding $1.0 \mathrm{ml}$ of $20 \mathrm{mM}$ Hepes, $\mathrm{pH} 7.4$, $1 \%$ Triton X-100, $10 \%$ glycerol (vol/vol), and $0.1 \mathrm{mg} / \mathrm{ml} \mathrm{BSA}$ and cells were left at room temperature for $20 \mathrm{~min}$ without agitation. The cellbound radioactivity was counted in a gamma counter. Nonspecific binding was determined for two concentrations of ${ }^{125}$ I-PDGF in each experiment by preincubating triplicate wells with 50 -fold excess of purified PDGF for $1 \mathrm{~h}$ at $37^{\circ} \mathrm{C}$. Specific binding was calculated by subtracting the counts per minute for nonspecific binding from the 
total counts per minute bound per well. The nonionic detergent Triton $\mathrm{X}-100$ was used to solubilize cell-associated ${ }^{125}$ I-PDGF without solubilizing dish-bound ${ }^{125}$ I-PDGF as originally described by Heldin et al. (26) and by Bowen-Pope and Ross (27). This method circumvents the high nonspecific binding contributed by ${ }^{125}$ I-PDGF that binds to the plastic. Scatchard analysis of the binding data was performed using the computer software LIGAND.

\section{Statistical methods}

Data, expressed as mean $\pm \mathrm{SD}$, were analyzed by analysis of variance followed by paired $t$ test.

\section{Results}

Results of the immunocytochemical studies performed to characterize and confirm the identity of FSC are summarized in Table I. Strongly positive granular staining for fibronectin and laminin and fibrillar staining for desmin and vimentin were observed in the cytoplasm of FSC in primary (Fig. 1) and passaged cultures. Our findings confirm previous reports $(2,5$, $28,29)$ and exclude the presence of contaminating Kupffer and sinusoidal endothelial cells or hepatocytes. Transmission electron microscopy studies on primary cultures of FSC revealed the presence of numerous large lipid droplets in the cytoplasm associated with intermediate filaments and dense bodies. The above features were still present after three serial passages, although the size and the number of the fat droplets progressively decreased and the number of intermediate filaments and dense bodies increased. At this stage a markedly enlarged rough endoplasmic reticulum containing homogeneous material was also observed. The characteristic cytoplasmic vitamin A autofluorescence was very intense in primary cultures of FSC and progressively decreased, becoming undetectable after the second or third subculture. Experiments included in this study were performed on cells between first and third passage from two different cell lines.

Table I. Immunofluorescence and Immunoperoxidase Staining of Rat Liver FSC

\begin{tabular}{|c|c|c|c|c|}
\hline \multicolumn{2}{|c|}{ Primary antibody* } & \multirow[b]{2}{*}{ Other staining ${ }^{\ddagger}$} & \multicolumn{2}{|c|}{ Results ${ }^{\S}$} \\
\hline Rabbit & Murine & & IF & IP \\
\hline & Rat Ia & & - & - \\
\hline & Desmin & & +++ & $+1++$ \\
\hline & Cytokeratin & & - & - \\
\hline Fibronectin & & & +++ & +++ \\
\hline Vimentin & & & +++ & ++ \\
\hline Myoglobin & & & ++ & ++ \\
\hline Laminin & & & +++ & +++ \\
\hline \multirow{3}{*}{ Factor VIII } & & & - & - \\
\hline & & $\begin{array}{c}\text { Endogenous } \\
\text { peroxidase }\end{array}$ & - & \\
\hline & & $\begin{array}{l}\text { Phalloidin } \\
\text { (F-actin) }\end{array}$ & +++ & \\
\hline
\end{tabular}

IF, immunofluorescence; IP, immunoperoxidase.

* Primary cultures of FSC were stained with the listed antibodies and counterstained with immunofluorescence and immunoperoxidase methods. A minimum of five random fields were examined for each marker in a blind manner.

${ }^{\ddagger}$ See Methods.

$\S+++$, Very strong; ++ , moderate; + , mild; - , negative.
The kinetics of DNA synthesis in quiescent FSC were studied after stimulation with each of the peptide mitogens (Fig. $2 A)$. The addition of PDGF, EGF, TGF-alpha, or bFGF induced a progressive increase in $\left[{ }^{3} \mathrm{H}\right] \mathrm{TdR}$ incorporation into DNA after 12-16 h, reaching a peak effect after $24 \mathrm{~h}$. TGFbeta did not stimulate $\left[{ }^{3} \mathrm{H}\right] \mathrm{TdR}$ incorporation into DNA at any of the time points tested. Fig. $2 B$ shows dose-response curves for the effect of the growth factors. Time-course and dose-response experiments show that PDGF was the most potent inducer of DNA synthesis in quiescent FSC. PDGF stimulated $\left[{ }^{3} \mathrm{H}\right] \mathrm{TdR}$ incorporation into DNA in a dose-dependent manner, with a half-maximal and maximal stimulation at $\sim 2$ and $10 \mathrm{ng} / \mathrm{ml}$, respectively. EGF, TGF-alpha, and bFGF, although less potent than PDGF, elicited a maximum three- to fourfold increase in DNA synthesis at doses ranging between 10 and $25 \mathrm{ng} / \mathrm{ml}$. Incubation of FSC with increasing doses of TGF-beta did not stimulate $\left[{ }^{3} \mathrm{H}\right] \mathrm{TdR}$ incorporation into DNA. The effects of PDGF and other peptides on DNA synthesis in FSC were confirmed by whole cell autoradiography as shown in Table II. Autoradiographic analysis showed a marked increase $(\sim 18$-fold) in labeling index induced by PDGF and, to a lesser extent, by EGF, TGF-alpha, or bFGF. No increase in percent of labeled nuclei was observed when the cells were incubated with TGF-beta alone.

Growth curve experiments for FSC in response to peptide growth factors were performed to demonstrate that the increase in $\left[{ }^{3} \mathrm{H}\right] \mathrm{TdR}$ incorporation into DNA is associated with cell growth. As shown in Fig. 3, PDGF markedly increased FSC growth after 3 and $6 \mathrm{~d}$ of incubation when compared with control. PDGF-induced cell growth was even more evident than the proliferative effect elicited by incubation with complete culture media. Incubation with EGF, TGF-alpha, and bFGF also induced an increase in cell number. The absence of growth stimulation after incubation with TGF-beta further confirmed that TGF-beta by itself is not a mitogen for FSC.

Since PDGF induced the most striking effect on DNA synthesis and cell growth, we attempted to characterize PDGF receptors on FSC. Cultured rat FSC showed significant and highly specific binding of ${ }^{125}$ I-PDGF as shown in Fig. 4. In this representative experiment the specific binding of ${ }^{125}$ I-PDGF ranged between 79 and $84 \%$. Half-maximal binding was at $150-180 \mathrm{pM}$ and saturation was at 550-700 pM (corresponding to 5-6 and $18-23 \mathrm{ng} / \mathrm{ml}$ of PDGF, respectively). Scatchard analysis of the ${ }^{125} \mathrm{I}$-PDGF binding data indicated a single class of receptors with an apparent $K_{\mathrm{d}}$ of $2.3 \times 10^{-10} \mathrm{M}$ and an average of $5 \times 10^{4}$ receptor sites per cell. This number of receptors is comparable to that observed in human fibroblasts (26) and human mesangial cells (30).

Although TGF-beta by itself did not stimulate DNA synthesis in FSC, we studied its effects on EGF or PDGF-induced DNA synthesis. As shown in Fig. 5, the addition of increasing doses of TGF-beta together with a maximal dose of EGF (Fig. $5 A$ ) or PDGF (Fig. $5 B$ ) induced a further increase in $\left[{ }^{3} \mathrm{H}\right] \mathrm{TdR}$ incorporation into DNA of FSC. The concentration of TGFbeta that induced the maximal increase in DNA synthesis in response to both EGF and PDGF was $1.0 \mathrm{ng} / \mathrm{ml}$.

\section{Discussion}

In the present study we demonstrated a potent mitogenic effect of PDGF and other polypeptide mitogens on well-characterized cultured rat liver FSC. With the exception of TGF-beta, 

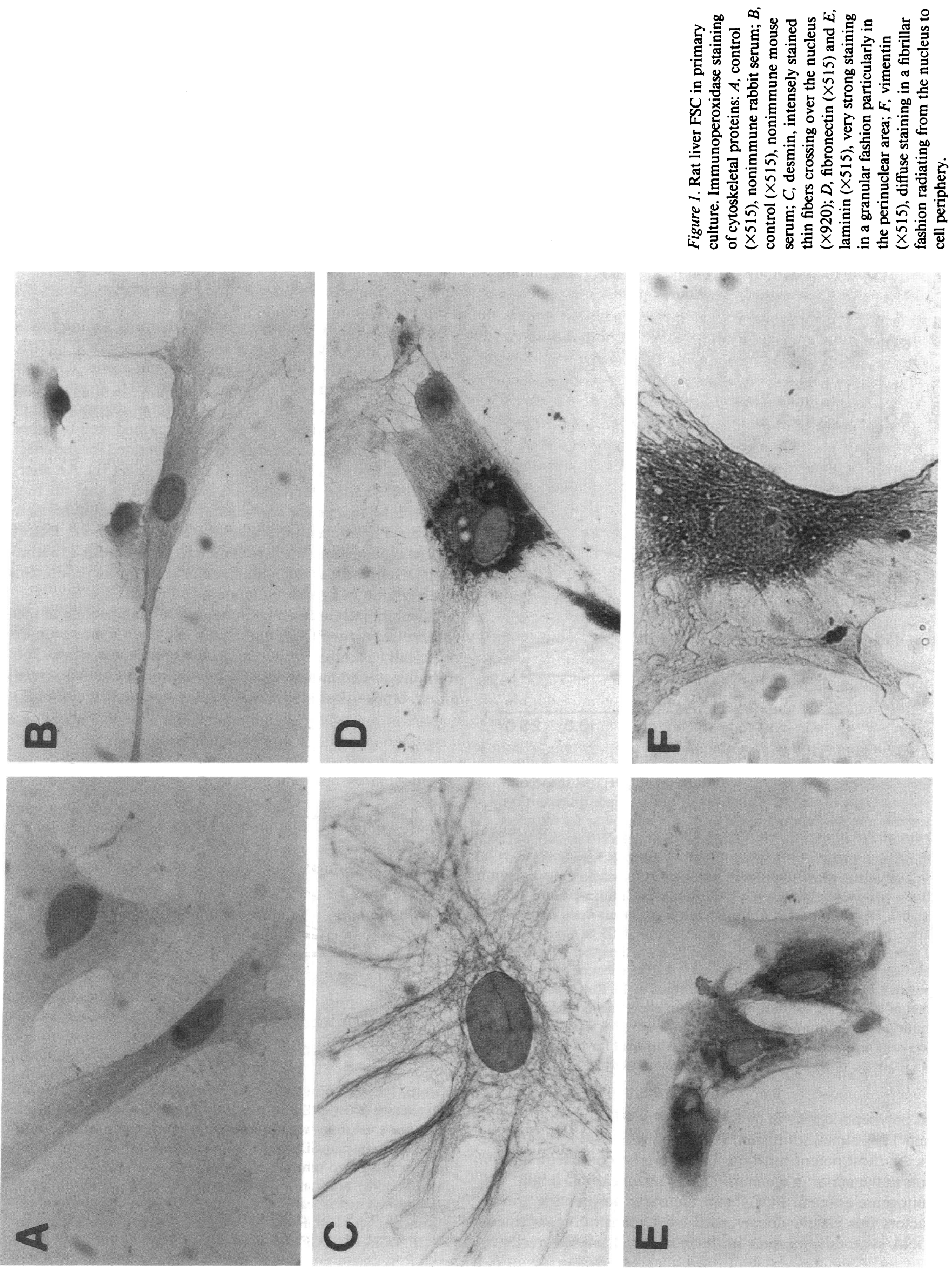


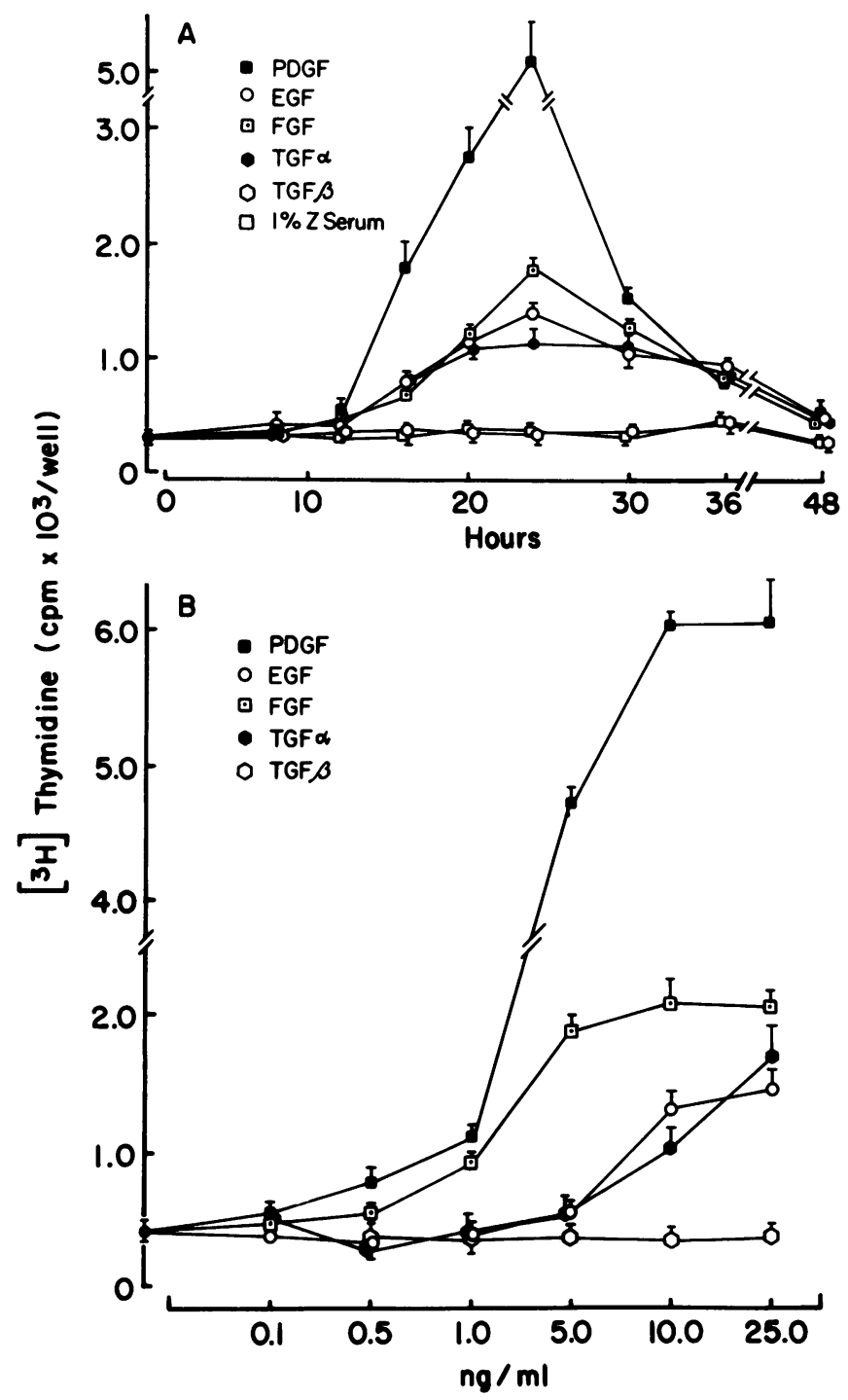

Figure 2. Effects of peptide growth factor(s) on $\left[{ }^{3} \mathrm{H}\right] \mathrm{TdR}$ incorporation into DNA of rat FSC. Confluent cells were made quiescent by incubation in $1 \%$ Zeta serum for $48 \mathrm{~h}$. $A$, Time course for the effect of PDGF (10 ng/ml), EGF (10 ng/ml), TGF-alpha (10 ng/ml), bFGF $(10 \mathrm{ng} / \mathrm{ml})$, and TGF-beta $(1 \mathrm{ng} / \mathrm{ml})$. Control wells were incubated in $1 \%$ Zeta serum alone. Cells were harvested at indicated time points after a 4-h pulsing period with $\left[{ }^{3} \mathrm{H}\right] \mathrm{TdR}(1.0 \mu \mathrm{Ci} / \mathrm{ml}$; see Methods for details). Data are mean \pm SD from three experiments done in triplicate. Changes were statistically significant $(P<0.05$ or higher degree of significance) at $16 \mathrm{~h}$ for PDGF and $20 \mathrm{~h}$ for the other growth factors except TGF-beta. $B$, Dose response for the effect of peptide growth factors. Incubations were performed in $1 \%$ Zeta serum for a total of $24 \mathrm{~h}$. Data are mean \pm SD for four experiments performed in triplicate. Changes were statistically significant $(P<0.05$ or higher degree of significance) starting at 0.5 and $1 \mathrm{ng} / \mathrm{ml}$ for PDGF and bFGF, respectively, and at $10 \mathrm{ng} / \mathrm{ml}$ for both EGF and TGF-alpha.

all polypeptide growth factors, including PDGF, bFGF, EGF, and TGF-alpha, stimulated DNA synthesis. PDGF stands out as the most potent mitogen for these cells, consistent with its role as the major mitogen for cells of mesenchymal origin. The mitogenic effect of PDGF and the other polypeptide growth factors was clearly documented by demonstrating enhanced DNA synthesis, increase in the number of labeled nuclei by
Table II. Effects of Various Peptide Growth Factors on DNA Synthesis Measured by Autoradiography

\begin{tabular}{lc}
\hline \multicolumn{1}{c}{ Condition } & $\begin{array}{c}\text { Labeling index } \\
\text { (\% of labeled nuclei) }\end{array}$ \\
\hline Control $(1 \% \mathrm{Z} \mathrm{serum})$ & $1.0 \pm 1.0$ \\
PDGF $(10 \mathrm{ng} / \mathrm{ml})$ & $19.7 \pm 3.0$ \\
EGF $(10 \mathrm{ng} / \mathrm{ml})$ & $7.7 \pm 0.25$ \\
TGF-alpha $(10 \mathrm{ng} / \mathrm{ml})$ & $4.1 \pm 0.3$ \\
Basic FGF $(10 \mathrm{ng} / \mathrm{ml})$ & $7.2 \pm 0.1$ \\
TGF-beta $(1 \mathrm{ng} / \mathrm{ml})$ & 0
\end{tabular}

Data represent mean $\pm \mathrm{SD}$ of two experiments done in triplicate.

autoradiography, and actual growth of the cells. Of interest is the similarity of the kinetics of the time course for $\left[{ }^{3} \mathrm{H}\right] \mathrm{TdR}$ incorporation among the polypeptide mitogens. All four growth factors increased DNA synthesis by $20 \mathrm{~h}$, an effect that peaked at $24 \mathrm{~h}$. This finding implies a direct mitogenic effect of all four peptides and not an indirect effect mediated by other growth factors as has been recently demonstrated for the effect of IL-1 on fibroblasts and smooth muscle cells (31). An alternative explanation for these similar kinetics is that all four polypeptides induce the coordinate release of an intermediate mitogen. The concentrations at which all four growth factors elicited mitogenic activity are similar to those required to stimulate DNA synthesis in other cells and to modulate production and secretion of matrix component (32-34).

The binding studies clearly document the presence of specific receptors for PDGF on FSC. These studies, however, do not clearly identify the receptor subtype(s) present on FSC since the labeled human PDGF, predominantly an AB heterodimer, binds to both types of receptors thus far described (35).

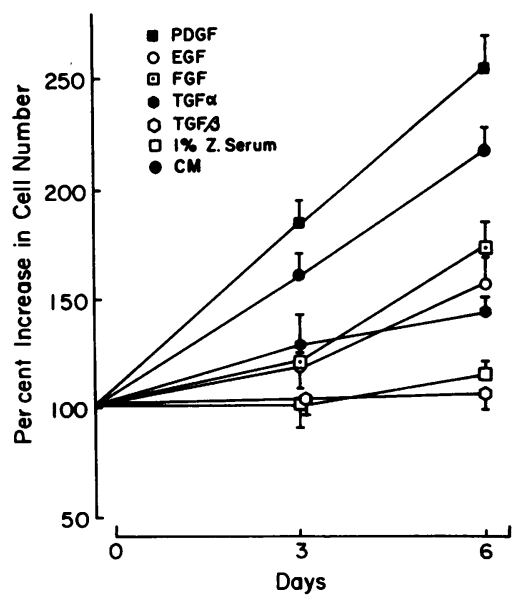

Figure 3. Effects of peptide growth factors and complete culture media (CM; i.e., Waymouth's medium containing $10 \%$ horse serum and $10 \%$ calf serum) on the growth of rat FSC. Subconfluent FSC in 12- or 24-well dishes were placed in $1 \%$ Zeta serum and incubated with each growth factor for 3 or $6 \mathrm{~d}$. All peptides were added at a concentration of 10 $\mathrm{ng} / \mathrm{ml}$ with the exception of TGF-beta (1.0

$\mathrm{ng} / \mathrm{ml}$ ). The cells were then trypsinized and counted using a Coulter cell counter (Coulter Electronics, Inc.). Fresh medium containing the same test conditions was added to the remaining wells at each time point. Data (mean $\pm \mathrm{SD}$ ), expressed as percentage increase of cell number relative to time controls incubated in $1 \%$ Zeta serum alone (see Methods), are from three experiments done in triplicate.

Changes were statistically significant $(P<0.05$ or higher degree of significance) for PDGF and culture media starting at day 3 and for bFGF, EGF, and TGF-alpha at day 6. 


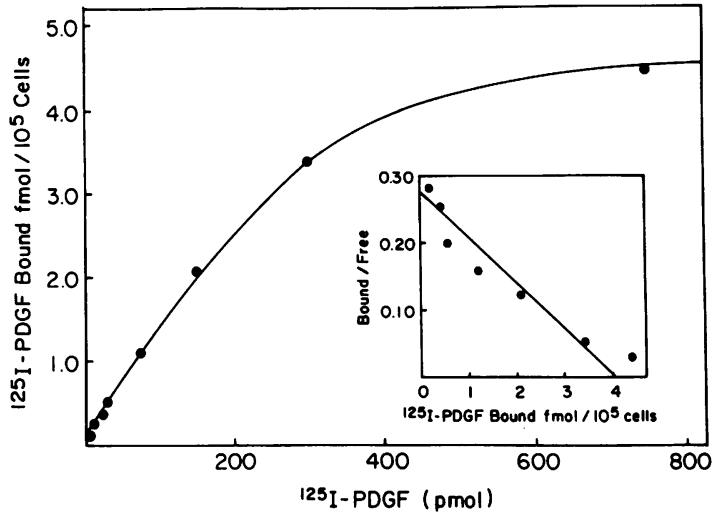

Figure 4. Specific binding of ${ }^{125} \mathrm{I}-\mathrm{PDGF}$ to rat FSC in monolayer. Triplicate wells of confluent FSC were incubated with ${ }^{125}$ I-PDGF at the concentrations shown for $2 \mathrm{~h}$ at $4^{\circ} \mathrm{C}$. Nonspecific binding was determined at two doses and was subtracted from the total binding to determine the specific binding. Ordinate indicates bound activity. Values shown are fmol bound $/ 10^{5}$ cells. Inset, Scatchard analysis of the ${ }^{125}$ I-PDGF binding data, representative of three experiments.

The precise number and distribution of the various types of PDGF receptors present on FSC remains to be determined.

The ability of PDGF, bFGF, EGF, and TGF-alpha to stimulate DNA synthesis independently demonstrates that each of these polypeptides functions as a complete growth factor for FSC, unlike the requirement for competence and progression factors which appears to be a unique property for BALB/c 3T3 cells (36).

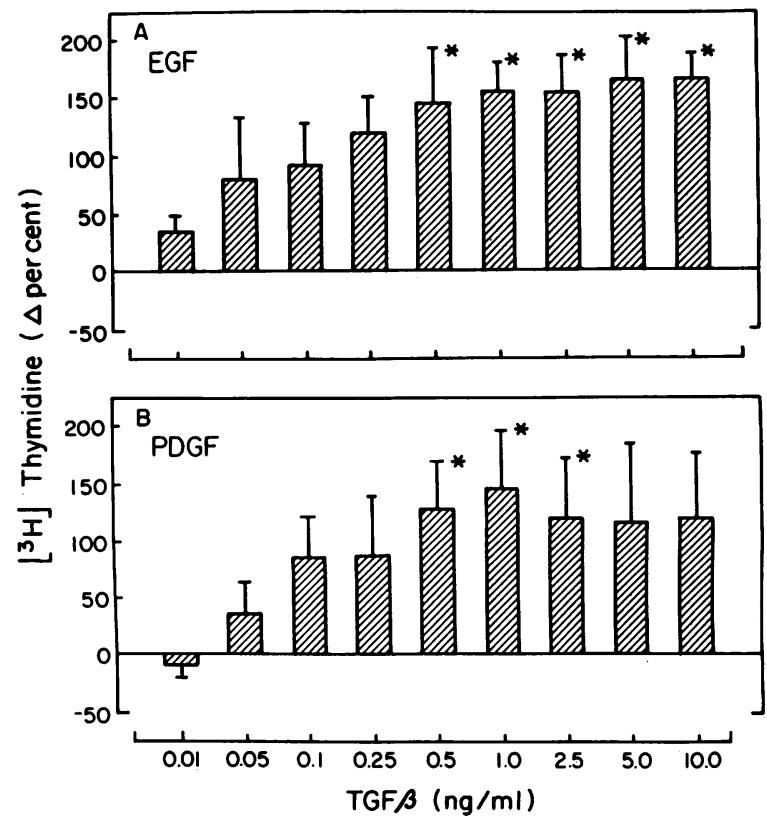

Figure 5. Effect of TGF-beta on $\left[{ }^{3} \mathrm{H}\right] \mathrm{TdR}$ incorporation into DNA of quiescent rat FSC induced by EGF $(A)$ or PDGF $(B)$. Confluent rat FSC were placed in $1 \%$ Zeta serum for $48 \mathrm{~h}$. Increasing doses of TGF-beta were then added immediately before the addition of PDGF $(10 \mathrm{ng} / \mathrm{ml})$ or EGF $(10 \mathrm{ng} / \mathrm{ml})$ to the wells. Data (mean \pm SD), expressed as the percent change relative to PDGF or EGF alone, are from three experiments done in triplicate. *, Significant difference $(P<0.05)$ from EGF or PDGF alone.
TGF-beta, found in relatively high concentrations in platelets, macrophages, and T lymphocytes (18), appears to have an important role in the tissue repair process. TGF-beta has been shown to elicit multiple biological effects depending on the cell type, epithelial or mesenchymal, and the presence of other growth factors. Accordingly, TGF-beta can either stimulate or inhibit cell proliferation and may regulate the action of other growth factors (37). Our results indicate that although TGFbeta by itself is not a mitogen for FSC it potentiates the mitogenic response of FSC to EGF and PDGF, and are consistent with the observation that TGF-beta participates in tissue repair. The mechanisms by which TGF-beta potentiates the mitogenic effects of PDGF or EGF cannot be determined from these studies. TGF-beta may increase the number or affinity of PDGF or EGF receptors, as it has already been shown for other cell types (38). Of interest is the recent report that TGFbeta differentially regulates the expression of various types of PDGF receptor subunits. According to the model proposed by Gronwald et al. (39), it is likely that the potentiation of the mitogenic effect of recombinant PDGF used in our studies (B, $B$ homodimer) is due to upregulation of the receptor subunits that recognize this PDGF isoform. In addition, or alternatively, the effect of TGF-beta may be mediated at sites distal to the binding of PDGF or EGF. For example, TGF-beta may modulate any of several transduction mechanisms involved in the mitogenic effect of these two peptides.

Although the in vivo biologic relevance of our studies remains speculative, much evidence supports the contention that our in vitro findings may help understand pathogenic mechanisms involved in liver pathology. Macrophage activation is considered a key factor in the pathogenesis of several fibrogenic diseases, including liver cirrhosis (40), and the release of PDGF from activated macrophages has been proposed to play a major role in the continuing process of fibrogenesis. Activation of macrophages in vitro induces PDGF release which accounts for $\sim 50-70 \%$ of the total macrophage-derived mitogenic activity (17). Therefore the release of PDGF by activated macrophages, including perhaps Kupffer cells, may represent a major stimulus for FSC proliferation and differentiation in conditions of long-standing, self-perpetuating inflammation of the liver lobule, and thus lead to progressive fibrosis. In this context, bFGF, EGF, and TGF-alpha, similarly released by inflammatory cells, including macrophages and platelets, may contribute to the proliferative response of FSC.

These studies demonstrating a potent mitogenic effect of PDGF and other polypeptide growth factors for FSC raise the possibility that they have other biologic effects on these cells. Most of these peptides are known to modulate matrix components as well as enzymes involved in matrix metabolism (32, 41). Moreover, activated macrophages, a major source of polypeptide mitogens in the condition of chronic inflammation, have been shown to elaborate and secrete matrix proteinases capable of degrading basement membrane (42). In this regard recent studies have clearly demonstrated that changes in the hepatic subendothelial matrix may induce activation of FSC associated with production of type I collagen, which in turn could perpetuate this activated state (43). Therefore, the eventual role of polypeptide growth factors in inducing FSC proliferation must be seen in a context of complex interactions between soluble factors and perturbation of the normal pattern of extracellular matrix. 


\section{Acknowledgments}

The authors thank Dr. Medhat Hassan and the electron microscopy unit at the Veterans Administration Medical Center for performing the electron microscopy studies, and Mary F. Abbuhl, M.B., Department of Pathology, Case Western Reserve University, for performing the immunoperoxidase staining. The authors also wish to thank Dr. Steven N. Emancipator, Department of Pathology, Case Western Reserve University, for his helpful advice and support.

This work was supported by Veterans Administration Research funds and National Institutes of Health grants DK-33665. H. E. Abboud is an Established Investigator of the American Heart Association L. Gesualdo is a fellow of the American Heart Association, Northeast Ohio Affiliate.

\section{References}

1. Blomhoff, R., M. Rasmussen, A. Nilsson, K. R. Norum, T. Berg, W. S. Blaner, M. Kato, J. R. Mertz, D. S. Goodman, U. Eriksson, and P. A. Peterson. 1985. Hepatic retinol metabolism. J. Biol. Chem. 260:13560-13565.

2. De Leeuw, A. M., S. P. McCarthy, A. Geerts, and D. L. Knook. 1984. Purified rat liver fat-storing cells in culture divide and contain collagen. Hepatology (Baltimore). 4:392-403.

3. Friedman, S. L., F. J. Roll, J. Boyles, and D. M. Bissell. 1985. Hepatic lipocytes: the principal collagen-producing cells of normal liver. Proc. Natl. Acad. Sci. USA. 82:8681-8685.

4. Kawase, T., Y. Shiratori, and T. Sugimoto. 1986. Collagen production by rat liver fat-storing cells in primary culture. Exp. Cell Biol. 54:183-192.

5. Maher, J. J., S. L. Friedman, F. J. Roll, and D. M. Bissell. 1988. Immunolocalization of laminin in normal rat liver and biosynthesis of laminin by hepatic lipocytes in primary culture. Gastroenterology. 94:1053-1062.

6. Arenson, D. M., S. L. Friedman, and D. M. Bissell. 1988. Formation of extracellular matrix in normal rat liver: lipocytes as a major source of proteoglycan. Gastroenterology. 95:441-447.

7. Clement, B., J. A. Grimaud, J. P. Campion, Y. Deugnier, and A. Guillouzo. 1986. Cell types involved in collagen and fibronectin production in normal and fibrotic human liver. Hepatology (Baltimore). 6:225-234.

8. Maher, J. J., D. M. Bissell, S. L. Friedman, and F. J. Roll. 1988. Collagen measured in primary cultures of normal rat hepatocytes derives from lipocytes within the monolayer. J. Clin. Invest. 82:450-459.

9. Kent, G., S. Gay, T. Inouye, R. Bahu, O. T. Minick, and H. Popper. 1976. Vitamin A-containing lipocytes and formation of type III collagen in liver injury. Proc. Natl. Acad. Sci. USA. 73:3719-3722.

10. McGee, J. O., and R. Patrick. 1972. The role of perisinusoidal cells in hepatic fibrogenesis: an electron microscopy study of acute carbon tetrachloride injury. Lab. Invest. 26:429-440.

11. Mak, K. M., M. A. Leo, and C. S. Lieber. 1984. Alcoholic liver injury in baboons: transformation of lipocytes to transitional cells. Gastroenterology. 87:188-200.

12. Ballardini, G., S. Degli Esposti, F. B. Bianchi, L. Badiali De Giorgi, A. Faccani, L. Biolchini, C. A. Busachi, and E. Pisi. 1983. Correlation between Ito cells and fibrogenesis in an experimental model of hepatic fibrosis: a sequential stereological study. Liver. 3:58-63.

13. Milani, S., H. Herbst, D. Shuppan, E. G. Hahn, and H. Stein. 1989. In situ hybridization for procollagen types I, III and IV mRNA in normal and fibrotic rat liver: evidence for predominant expression in nonparenchymal liver cells. Hepatology (Baltimore). 10:84-92.

14. Mak, K. M., and C. S. Lieber. 1988. Lipocytes and transitional cells in alcoholic liver disease: a morphometric study. Hepatology (Baltimore). 8:1027-1033.

15. Heldin, C. H., B. Westermark, and A. Wasteson. 1981. Demon- stration of an antibody against platelet-derived growth factor. Exp. Cell Res. 136:255-261.

16. Shimokado, K., E. W. Raines, D. K. Madtes, T. B. Barret, E. P. Benditt, and R. Ross. 1985. A significant part of macrophage-derived growth factor consists of at least two forms of PDGF. Cell. 43:277-286.

17. Ross, R., E. W. Raines, and D. F. Bowen-Pope. 1986. The biology of platelet-derived growth factor. Cell. 46:155-169.

18. Sporn, M. B., and A. B. Roberts. 1986. Peptide growth factors and inflammation, tissue repair, and cancer. J. Clin. Invest. 78:329332 .

19. Braun, L., J. E. Mead, M. Panzica, R. Mikumo, G. I. Bell, and N. Fausto. 1988. Transforming growth factor beta mRNA increases during liver regeneration: a possible paracrine mechanism of growth regulation. Proc. Natl. Acad. Sci. USA. 85:1539-1543.

20. Mead, J. E., and N. Fausto. 1989. Transforming growth factor alpha may be a physiological regulator of liver regeneration by means of an autocrine mechanism. Proc. Natl. Acad. Sci. USA. 86:15581562.

21. Friedman, S. L., and M. P. J. Arthur. 1987. Lipocyte growth is stimulated by rat Kupffer cells partly via release of platelet-derived growth factor (PDGF)-like activity. Hepatology (Baltimore). 7:1048. (Abstr.)

22. Matsuoka, M., N. Pham, and H. Tsukamoto. 1989. Differential effects of interleukin-1 alpha, tumor necrosis factor alpha, and transforming growth factor beta 1 on cell proliferation and collagen formation by cultured fat-storing cell. Liver. 9:71-78.

23. Friedman, S. L., and F. J. Roll. 1987. Isolation and culture of hepatic lipocytes, Kupffer cells, and sinusoidal endothelial cells by density gradient centrifugation with stractan. Anal. Biochem. 161:207-218.

24. Wisse, E. 1974. Observation on the fine structure and peroxidase cytochemistry of normal rat Kupffer cells. J. Ultrastruct. Res. 46:393-426.

25. Stein, G. H., and R. Yanishevsky. 1979. Autoradiography. Methods Enzymol. 58:279-292.

26. Heldin, C. H., B. Westermark, and A. Wasteson. 1981. Specific receptors for platelet-derived growth factor on cell derived from connective tissue and glia. Proc. Natl. Acad. Sci. USA. 78:3664-3668.

27. Bowen-Pope, D. F., and R. Ross. 1982. Platelet-derived growth factor. II. Specific binding to cultured cells. J. Biol. Chem. 257:51615171.

28. Yokoi, Y., T. Namihisa, H. Kuroda, I. Komatsu, A. Miyazaki, S. Watanabe, and K. Usui. 1984. Immunocytochemical detection of desmin in fat-storing cells (Ito cells). Hepatology (Baltimore). 4:709714 .

29. Takase, S., M. A. Leo, T. Nouchi, and C. S. Lieber. 1988. Desmin distinguishes cultured fat-storing cells from myofibroblasts, smooth muscle cells and fibroblasts in the rat. J. Hepatol. (Amst.). 6:267-276.

30. Shultz, P. J., P. E. DiCorleto, B. J. Silver, and H. E. Abboud. 1988. Mesangial cells express PDGF mRNAs and proliferate in response to PDGF. Am. J. Physiol. 255:F674-F684.

31. Raines, E. W., S. K. Dower, and R. Ross. 1989. Interleukin-1 mitogenic activity for fibroblasts and smooth muscle cells is due to PDGF-AA. Science (Wash. DC). 243:393-396.

32. Duel, T. F., and J. S. Huang. 1984. Platelet-derived growth factor. Structure, function, and roles in normal and transformed cells. J. Clin. Invest. 74:669-676.

33. Chua, C. C., D. E. Geiman, G. H. Keller, and R. L. Ladda. 1985. Induction of collagenase secretion in human fibroblast culture by growth promoting factors. J. Biol. Chem. 260:5213-5216.

34. Globus, R. K., P. Patterson-Buckendahl, and D. Gospodarowicz. 1988. Regulation of bovine bone cell proliferation by fibroblast growth factor and transforming growth factor beta. Endocrinology. 123:98-105.

35. Bowen-Pope, D. F., C. E. Hart, and R. A. Seifert. 1989. Sera 
and conditioned media contain different isoforms of platelet-derived growth factor (PDGF) which bind to different classes of PDGF receptors. J. Biol. Chem. 264:2502-2508.

36. Stiles, C. D., G. T. Capone, C. D. Scher, H. N. Antoniades, J. J Van Wyk, and W. J. Pledger. 1979. Dual control of cell growth by somatomedins and platelet-derived growth factor. Proc. Natl. Acad. Sci. USA. 76:1279-1283.

37. Assoian, R. K., G. R. Grotendorst, D. M. Miller, and M. B. Sporn. 1984. Cellular transformation by coordinated action of three peptide growth factors from human platelets. Nature (Lond.) 309:804-806.

38. Assoian, R. K. 1985. Biphasic effects of type beta transforming growth factor on epidermal growth factor receptors in NKR fibroblasts. J. Biol. Chem. 260:9613-9617.

39. Gronwald, R. G. K., R. A. Seifert, and D. F. Bowen-Pope. 1989. Differential regulation of expression of two platelet-derived growth factor receptor subunits by transforming growth factor-beta. $J$. Biol. Chem. 264:8120-8125.

40. Popper, H., and S. Udenfriend. 1970. Hepatic fibrosis: correlation of biochemical and morphological investigations. Am. J. Med. 49:707-721.

41. Bauer, E. A., T. W. Cooper, J. S. Huang, J. Altman, and T. F. Duel. 1985. Stimulation of in vitro human skin collagenase expression by platelet-derived growth factor. Proc. Natl. Acad. Sci. USA. 82:4132-4136.

42. Garbisa, S., M. Ballin, D. Daga-Gordini, G. Fastelli, M. Naturale, A. Negro, G. Semenzato, and L. A. Liotta. 1986. Transient expression of type IV collagenolytic metalloproteinase by human mononuclear phagocytes. J. Biol. Chem. 261:2369-2375.

43. Friedman, S. L., F. J. Roll, J. Boyles, D. M. Arenson, and D. M. Bissell. 1989. Maintenance of differentiated phenotype of cultured rat hepatic lipocytes by basement membrane matrix. J. Biol. Chem. 264:10756-10762. 